\title{
Neonatal Tissue Damage Promotes Spike Timing-Dependent Synaptic Long-Term Potentiation in Adult Spinal Projection Neurons
}

\author{
Jie Li and Mark L. Baccei \\ Pain Research Center, Department of Anesthesiology, University of Cincinnati Medical Center, Cincinnati, Ohio 45267
}

Mounting evidence from both humans and rodents suggests that tissue damage during the neonatal period can "prime" developing nociceptive pathways such that a subsequent injury during adulthood causes an exacerbated degree of pain hypersensitivity. However, the cellular and molecular mechanisms that underlie this priming effect remain poorly understood. Here, we demonstrate that neonatal surgical injury relaxes the timing rules governing long-term potentiation (LTP) at mouse primary afferent synapses onto mature lamina I projection neurons, which serve as a major output of the spinal nociceptive network and are essential for pain perception. In addition, whereas LTP in naive mice was only observed if the presynaptic input preceded postsynaptic firing, early tissue injury removed this temporal requirement and LTP was observed regardless of the order in which the inputs were activated. Neonatal tissue damage also reduced the dependence of spike-timing-dependent LTP on NMDAR activation and unmasked a novel contribution of $\mathrm{Ca}^{2+}$-permeable AMPARs. These results suggest for the first time that transient tissue damage during early life creates a more permissive environment for the production of LTP within adult spinal nociceptive circuits. This persistent metaplasticity may promote the excessive amplification of ascending nociceptive transmission to the mature brain and thereby facilitate the generation of chronic pain after injury, thus representing a novel potential mechanism by which early trauma can prime adult pain pathways in the CNS.

Key words: development; dorsal horn; injury; spinal cord; synaptic plasticity

Significance Statement

Tissue damage during early life can "prime" developing nociceptive pathways in the CNS, leading to greater pain severity after repeat injury via mechanisms that remain poorly understood. Here, we demonstrate that neonatal surgical injury widens the timing window during which correlated presynaptic and postsynaptic activity can evoke long-term potentiation (LTP) at sensory synapses onto adult lamina I projection neurons, which serve as a major output of the spinal nociceptive circuit and are essential for pain perception. This persistent increase in the likelihood of LTP induction after neonatal injury is predicted to favor the excessive amplification of ascending nociceptive transmission to the mature brain in response to subsequent injury and thereby exacerbate chronic pain.

\section{Introduction}

Infants treated in a neonatal intensive care unit sustain repetitive tissue injuries due to essential medical interventions (Stevens et al., 2003; Carbajal et al., 2008). Emerging clinical evidence suggests that such interventions evoke long-term increases in pain sensitivity in response to prolonged or repeated noxious stimu-

Received Sept. 23, 2015; revised March 18, 2016; accepted April 8, 2016.

Author contributions: J.L. and M.L.B. designed research; J.L. performed research; J.L. and M.L.B. analyzed data; J.L. and M.L.B. wrote the paper.

This work was supported by the National Institutes of Health (Grant NS080889 to M.L.B.). We thank Elizabeth Serafin for technical support on the project.

Correspondence should be addressed to Mark L. Baccei, PhD, Pain Research Center, Dept. of Anesthesiology, University of Cincinnati Medical Center, 231 Albert Sabin Way, Cincinnati, OH 45267. E-mail: mark.baccei@uc.edu. DOI:10.1523/JNEUROSCI.3547-15.2016

Copyright $\odot 2016$ the authors $\quad 0270-6474 / 16 / 365405-12 \$ 15.00 / 0$ lation (Hermann et al., 2006; Hohmeister et al., 2010). In addition, preclinical studies have demonstrated that tissue damage during a critical period of early life leads to an exacerbated degree of pain hypersensitivity after repeat injury during adulthood (Ren et al., 2004; Hohmann et al., 2005; Chu et al., 2007; Walker et al., 2009; Beggs et al., 2012) provided that the second insult occurs within the same area as the initial trauma (Ren et al., 2004; Chu et al., 2007). Collectively, these findings suggest that neonatal tissue damage causes a localized "priming" of adult spinal pain circuits that contributes to an exaggerated response to future noxious stimulation. However, the cellular and molecular mechanisms underlying this priming effect remain poorly understood.

Our recent work has shown that neonatal tissue damage significantly increases the efficacy of primary afferent synapses onto mature lamina I projection neurons (Li et al., 2015), which serve 

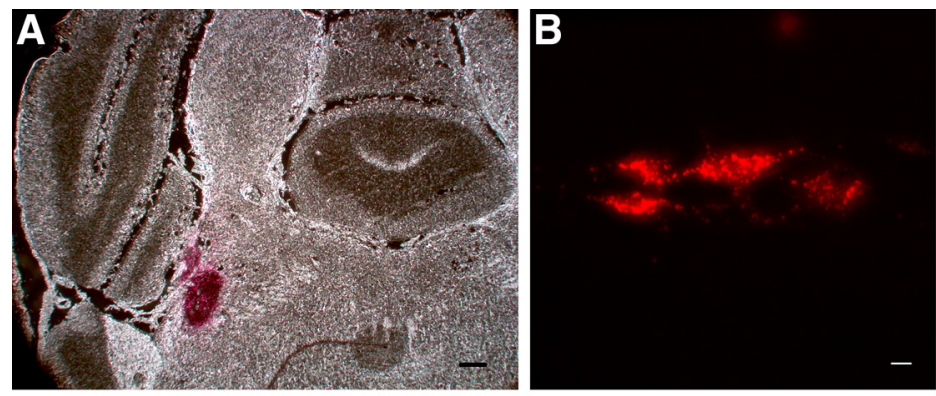

E1
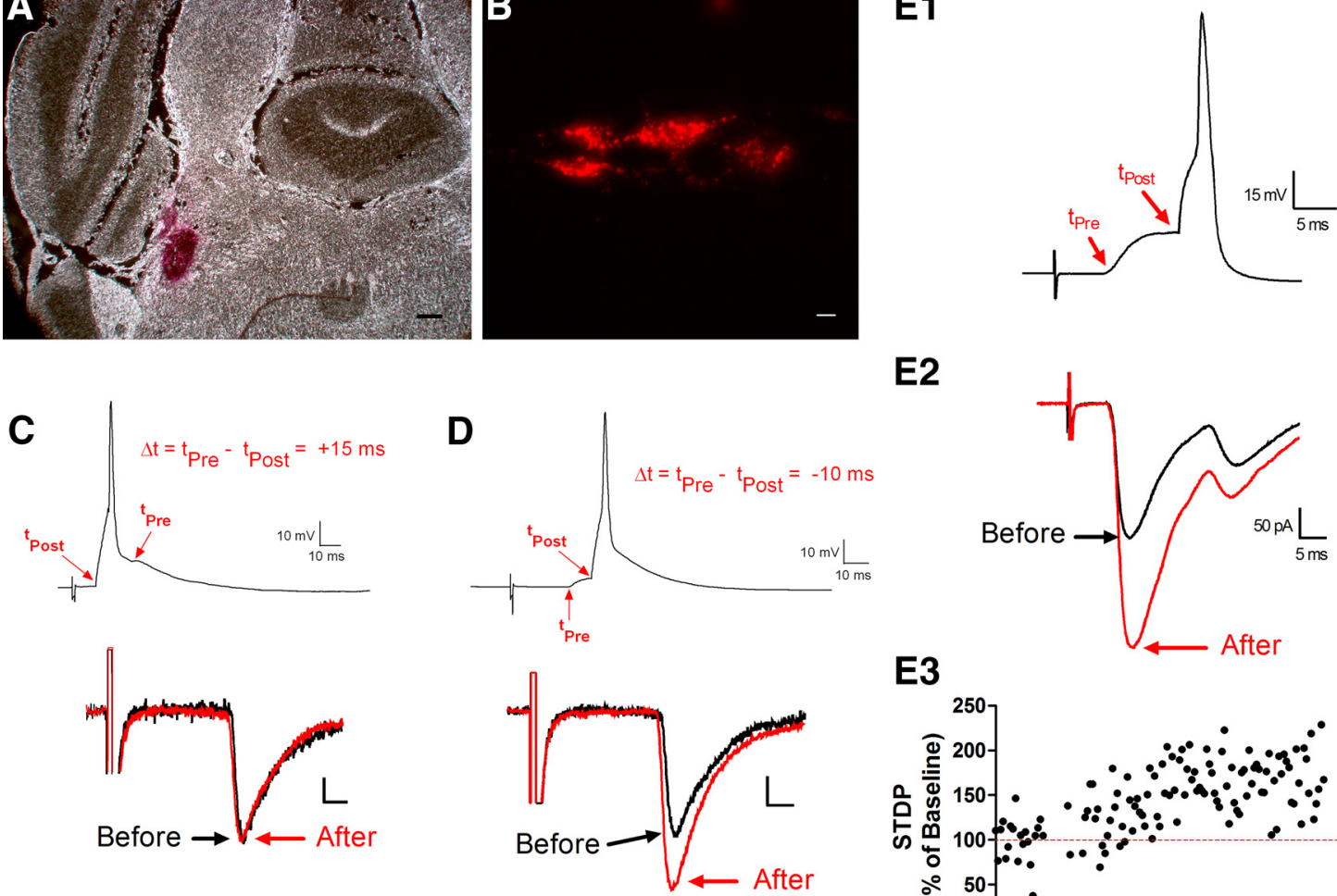

E2

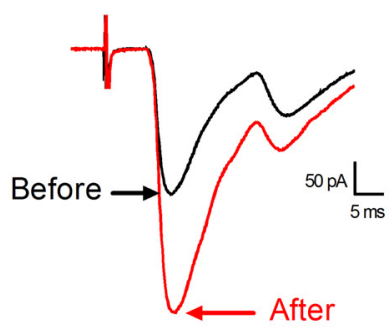

E3

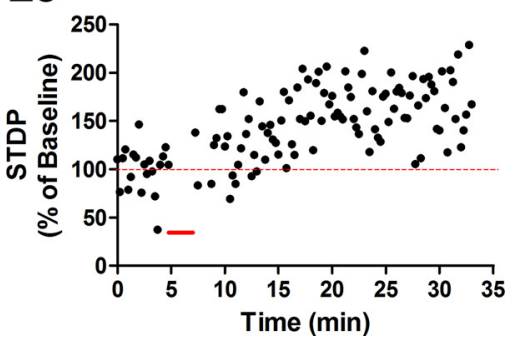

Figure 1. STDP at primary afferent synapses onto spinal projection neurons. $A$, Example of Dil injection into the parabrachial nucleus of the adult mouse brain. Scale bar, $200 \mu \mathrm{m} . \boldsymbol{B}$, Retrogradely labeled neurons were visible within lamina I in a sagittal spinal cord slice preparation. Scale bar, $10 \mu \mathrm{m}$. C, Postsynaptic AP discharge was elicited in a mature projection neuron via intracellular current injection $15 \mathrm{~ms}$ before the onset of an EPSP evoked by primary afferent stimulation $(\Delta t=+15 \mathrm{~ms}$, top). Administration of the above pairing protocol ( $30 \mathrm{times}$ at $0.2 \mathrm{~Hz})$ failed to significantly alter the EPSC amplitude (bottom). Scale bar, $10 \mathrm{pA}, 5 \mathrm{~ms}$. D, In the same neuron, evoking postsynaptic APs $10 \mathrm{~ms}$ after the arrival of the afferent-mediated EPSP ( $\Delta t=-10 \mathrm{~ms}$; top) significantly potentiated EPSC amplitude (bottom). Scale bar, $10 \mathrm{pA}, 5 \mathrm{~ms}$. E, Another representative example of t-LTP observed at primary afferent synapses onto lamina I projection neurons after a pairing protocol (indicated by red bar in $E 3$ ) in which the presynaptic input preceded postsynaptic firing ( $\Delta t=-10 \mathrm{~ms}$ ).

as a major output of the spinal nociceptive network and are essential for the generation of inflammatory and neuropathic pain (Mantyh et al., 1997; Nichols et al., 1999). It is well established that the repetitive stimulation of nociceptive afferents evokes long-term potentiation (LTP) at their synapses onto projection neurons (Ikeda et al., 2003; Ikeda et al., 2006), which has been proposed as a mechanism by which excitation in ascending nociceptive pathways can be amplified within the spinal cord (Ruscheweyh et al., 2011; Sandkühler and Gruber-Schoffnegger, 2012). Therefore, neonatal tissue damage could prime adult spinal nociceptive circuits by persistently facilitating LTP at these synapses. However, the degree to which LTP at mature afferent synapses is influenced by early sensory experience has yet to be investigated.

Early injury could facilitate LTP in the adult dorsal horn by enhancing the magnitude of synaptic potentiation and/or increasing the likelihood that LTP occurs in response to a given sensory input by widening the timing window during which coincident presynaptic and postsynaptic firing must occur to cause LTP. Indeed, the properties of spike-timing-dependent plasticity (STDP) at excitatory synapses in the CNS are highly flexible (Dan and Poo, 2004; Larsen et al., 2010) and modulated by factors such as inhibitory tone (Fino et al., 2010; Paille et al., 2013), metabotropic signaling (Seol et al., 2007; Huang et al., 2013), and NMDAR composition (Shouval et al., 2002; Gerkin et al., 2007). Unfortunately, the precise temporal rules governing STDP in spinal projection neurons have yet to be identified under normal or pathological conditions.

Here, we demonstrate that neonatal surgical injury broadens the window for spike-timing-dependent LTP (t-LTP) at primary afferent synapses onto adult spinal projection neurons and abolishes the requirement that presynaptic firing precedes postsynaptic activity. These findings suggest that sensory synapses onto ascending projection neurons can remain primed for greater activity-dependent potentiation long after a transient neonatal injury has resolved, which could contribute to the observed increase in pain severity after subsequent injury.

\section{Materials and Methods}

Experiments. All experiments adhered to animal welfare guidelines established by the University of Cincinnati Institutional Animal Care and Use Committee.

Neonatal surgical injury. At postnatal day 3 (P3) or P21, female mice (FVB- $\operatorname{Tg}($ GadGFP)4570Swn; The Jackson Laboratory) were anesthetized with isoflurane $(2-3 \%)$ and a small incision was made through the skin and underlying muscle of the plantar hindpaw as described previously (Brennan et al., 1996; Li et al., 2013). The skin was immediately closed with 7-0 (at P3) or 5-0 (at P21) suture (Ethicon) and the wound fully healed in $\leq 2$ weeks. Littermate-matched controls, which were handled in an identical manner (including exposure to anesthesia) but did not receive hindpaw incision, were used for all experiments.

Identification of ascending spinal projection neurons. Approximately 1 week before euthanasia, adult mice (18-22 g) were anesthetized with a 

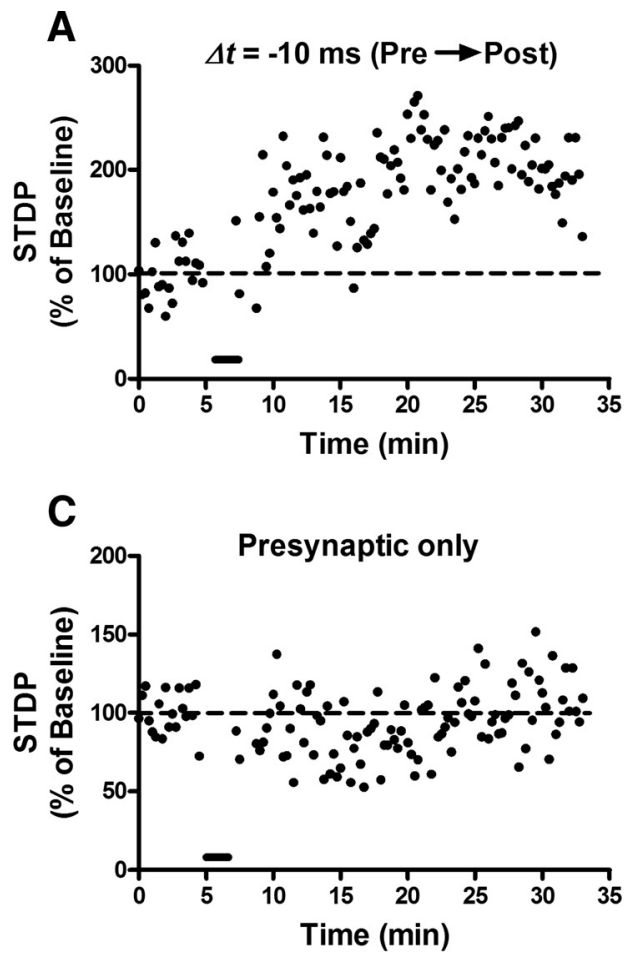
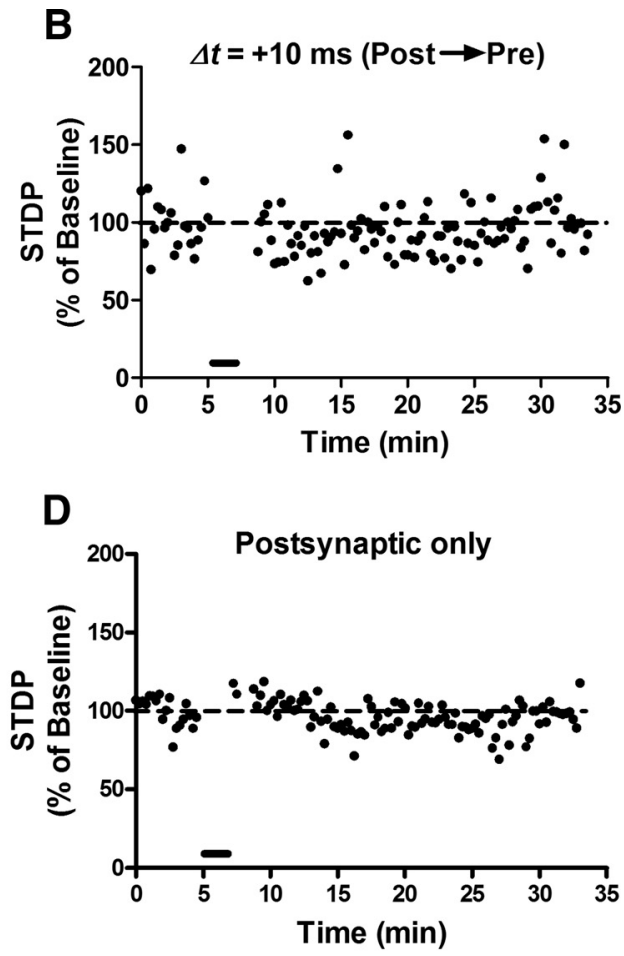

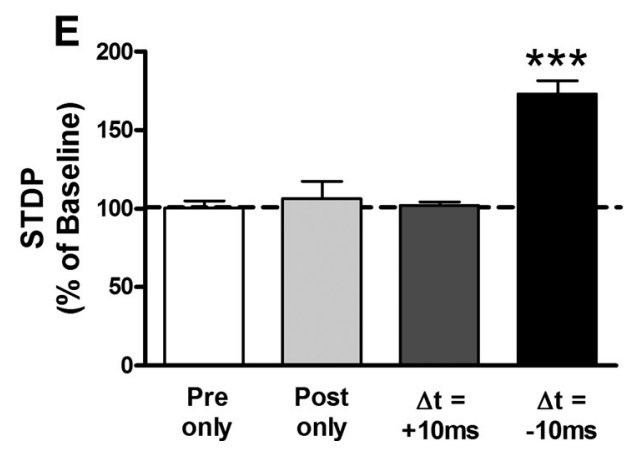

Figure 2. STDP is biased toward t-LTP at sensory synapses onto adult projection neurons. $A, B$, Representative plots of STDP (expressed as a percentage of baseline EPSC amplitude before pairing, where $100 \%$ indicates no change in synaptic efficacy) versus time, showing the effects of Pre $\rightarrow$ Post $(\boldsymbol{A})$ and Post $\rightarrow$ Pre $(\boldsymbol{B})$ pairing protocols (bar) on the efficacy of monosynaptic primary afferent input. $\boldsymbol{C}, \boldsymbol{D}$, Neither presynaptic $(\boldsymbol{C})$ nor postsynaptic (D) stimulation alone (30 stimuli at $0.2 \mathrm{~Hz}$ ) significantly modulated EPSC amplitude, demonstrating that correlated primary afferent and projection neuron activity was required to modify synaptic strength. $E$, Across the population of naive lamina I spino-parabrachial neurons sampled, highly correlated Pre $\rightarrow$ Post pairings ( $\Delta t=-10 \mathrm{~ms})$ produced significantt-LTP at primary afferent synapses $\left(n=5-7\right.$ in each group, ${ }^{* * *} p<0.001$ compared with all other groups; one-way ANOVA with Tukey's multiple-comparisons test). In contrast, Post $\rightarrow$ Pre pairings ( $\Delta t=+10 \mathrm{~ms}$ ) failed to significantly influence EPSC amplitude at afferent synapses onto projection neurons ( $p>0.05$ vs control groups).

mixture of ketamine $(90 \mathrm{mg} / \mathrm{kg})$ and xylazine $(10 \mathrm{mg} / \mathrm{kg})$ and secured in a stereotaxic apparatus. A single injection (100-150 nl) of FAST DiI oil $(2.5 \mathrm{mg} / \mathrm{ml})$ was administered into the parabrachial nucleus using a Hamilton microsyringe (62RN; $2.5 \mu$ l volume) equipped with a 28 gauge needle. Based on an atlas by Paxinos and Franklin (2012), the following stereotaxic coordinates were used (in millimeters relative to bregma): $4.8-5.0$ caudal, $1.2-1.4$ lateral, and 4.0-4.2 ventral.

In vitro spinal cord slice preparation. At P56-P70, mice were deeply anesthetized with sodium pentobarbital $(60 \mathrm{mg} / \mathrm{kg})$ and perfused with ice-cold dissection solution containing the following (in $\mathrm{mM}$ ): $250 \mathrm{su}-$ crose, $2.5 \mathrm{KCl}, 25 \mathrm{NaHCO}_{3}, 1.0 \mathrm{NaH}_{2} \mathrm{PO}_{4}, 6 \mathrm{MgCl}_{2}, 0.5 \mathrm{CaCl}_{2}$, and 25 glucose continuously bubbled with $95 \% \mathrm{O}_{2} / 5 \% \mathrm{CO}_{2}$. The lumbar spinal cord was isolated and immersed in low-melting-point agarose $(3 \%$ in above solution) at $37^{\circ} \mathrm{C}$, which was then cooled on ice. Parasagittal slices $(350-400 \mu \mathrm{m})$ with the L4-L5 dorsal roots attached (length 7-10 mm) were cut from the side ipsilateral to the injury using a vibrating microtome (7000smz-2; Campden Instruments). Slices were incubated for 15-20 $\mathrm{min}$ in a recovery solution containing the following (in $\mathrm{mM}$ ): 92 NMDG, $2.5 \mathrm{KCl}, 1.2 \mathrm{NaH}_{2} \mathrm{PO}_{4}, 30 \mathrm{NaHCO}_{3}, 20$ HEPES, 25 glucose, $5 \mathrm{Na}$ ascorbate, 2 thiourea, $3 \mathrm{Na}$ pyruvate, $10 \mathrm{MgSO}_{4}$, and $0.5 \mathrm{CaCl}_{2}$ (Ting et al., 2011) and then allowed to recover further in an oxygenated artificial CSF (aCSF) solution containing the following (in mM): $125 \mathrm{NaCl}, 2.5$ $\mathrm{KCl}, 25 \mathrm{NaHCO}_{3}, 1.0 \mathrm{NaH}_{2} \mathrm{PO}_{4}, 1.0 \mathrm{MgCl}_{2}, 2.0 \mathrm{CaCl}_{2}$, and 25 glucose for $\geq 1 \mathrm{~h}$ at room temperature.

Patch-clamp recordings from identified lamina I projection neurons. After recovery, slices were transferred to a submersion-type recording chamber (RC-22; Warner Instruments) and mounted on the stage of an upright microscope (BX51WI; Olympus). Slices were then perfused at room temperature with oxygenated aCSF at a rate of 3-6 $\mathrm{ml} / \mathrm{min}$.

Patch electrodes were constructed from thin-walled single-filamented borosilicate glass (1.5 mm outer diameter; World Precision Instruments) using a microelectrode puller (P-97; Sutter Instruments). Pipette resistances ranged from 4 to $6 \mathrm{M} \Omega$ and seal resistances were $>1 \mathrm{G} \Omega$. Patch electrodes were filled with an intracellular solution containing the following (in $\mathrm{mm}$ ): $130 \mathrm{~K}$-gluconate, $10 \mathrm{KCl}, 10 \mathrm{HEPES}, 10 \mathrm{Na}-$ phosphocreatine, $4 \mathrm{MgATP}$, and 0.3 $\mathrm{Na}_{2}$-GTP, pH 7.2 (295-300 mOsm).

Characterization of STDP at primary afferent synapses onto spinal projection neurons. Monosynaptic EPSCs, defined by a stable onset latency ( $\leq 2 \mathrm{~ms}$ variation) and an absence of failures in response to repetitive stimulation (Li et al., 2015), were evoked in projection neurons from a 
A

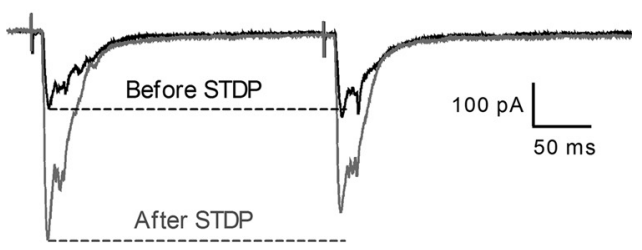

B

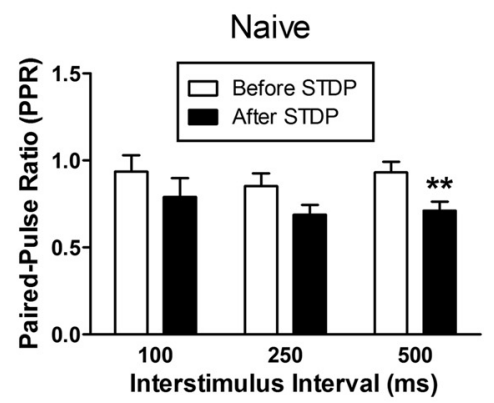

C

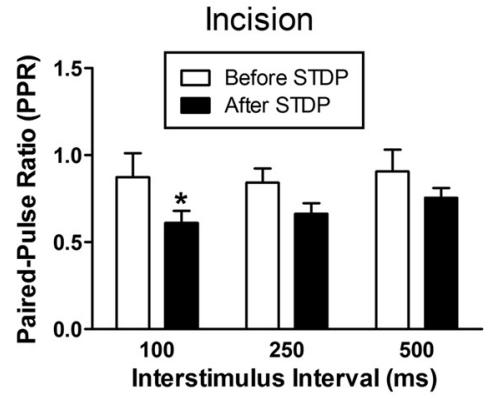

D

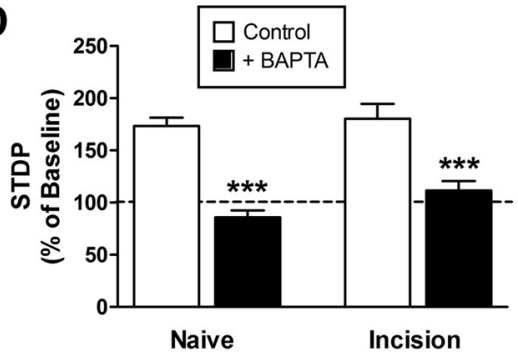

E

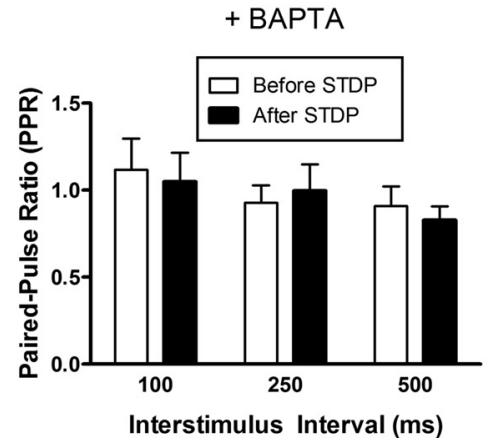

Figure 3. $\quad$ t-LTP at primary afferent synapses onto mature projection neurons involves enhanced presynaptic glutamate release and requires elevations in postsynaptic $\mathrm{Ca}^{2+}$ levels. $\boldsymbol{A}$, Examples of monosynaptic EPSCs evoked by a pair of identical electrical stimuli applied to the dorsal root at an interstimulus interval of $250 \mathrm{~ms}$, either before (black) or after (gray) the administration of the STDP protocol (Pre $\rightarrow$ Post pairing at $\Delta t=-10 \mathrm{~ms}$ ). $\boldsymbol{B}$, In adult lamina I projection neurons from naive mice, the STDP protocol produced a significant decrease in the observed paired-pulse ratio ( $n=7 ; p=0.0001$; RM tw0-way ANOVA; ${ }^{* *} p<0.01$; Bonferroni posttest for multiple comparisons). C, Projection neurons from adult mice which experienced hindpaw incision at P3 also demonstrated a significant reduction in paired-pulse ratio after holding potential of $-70 \mathrm{mV}$ by stimulation of the attached dorsal root (every $15 \mathrm{~s}$ at an intensity of $1-1.2 \times$ threshold). To characterize STDP, after the verification of a stable baseline EPSC amplitude for $\geq 5 \mathrm{~min}$, the same primary afferent stimulus was paired with a postsynaptic AP evoked by direct intracellular current injection $(300-800 \mathrm{pA} ; 5 \mathrm{~ms})$ at varying intervals $(\Delta t=+20 \mathrm{~ms}$ to $-50 \mathrm{~ms})$ under current-clamp conditions. After administration of the pairing protocol (30 pairs of stimuli at $0.2 \mathrm{~Hz}$ ), projection neurons were again voltage clamped at $-70 \mathrm{mV}$ and the primary afferent-evoked EPSCs recorded for $\geq 25 \mathrm{~min}$ to calculate a mean normalized change in EPSC amplitude (as a percentage of baseline). Control experiments involved administration of the presynaptic or postsynaptic stimulation alone (i.e., no pairing). In some cases, the above experiments were conducted in the presence of selective antagonists to NMDARs (AP5; $25 \mu \mathrm{M})$ or $\mathrm{Ca}^{2+}$-permeable AMPARs (IEM $1460 ; 10 \mu \mathrm{M})$.

Induction of frequency-dependent LTP $(f-L T P)$ in ascending projection neurons. Monosynaptic EPSCs were evoked in lamina I projection neurons (at $1-1.2 \times$ threshold; $100 \mu$ s duration) from a holding potential of $-70 \mathrm{mV}$ by dorsal root stimulation as described above. After confirmation of a stable baseline EPSC amplitude, the neuron was voltage clamped at $-30 \mathrm{mV}$ and 3 trains of high-frequency stimulation (HFS; $100 \mathrm{~Hz} ; 1 \mathrm{~s}$ ) were delivered to the dorsal root at $10 \mathrm{~s}$ intervals. The neuron was again voltage clamped at $-70 \mathrm{mV}$ and the amplitude of primary afferentevoked EPSCs monitored for $\geq 25 \mathrm{~min}$. The magnitude of f-LTP was measured by normalizing the average EPSC amplitude at $t=22-25 \mathrm{~min}$ after HFS to the mean baseline EPSC amplitude (as a percentage of baseline).

Measurements of intrinsic membrane excitability in spinal projection neurons. The resting membrane potential $\left(V_{\text {rest }}\right)$ was measured in ascending projection neurons $\sim 1$ min after establishment of the whole-cell patch-clamp configuration. Membrane capacitance was calculated using the built-in pClamp membrane test (applied at $33.3 \mathrm{~Hz}$ ); membrane resistance was measured using the hyperpolarization produced by a -20 pA current injection from $V_{\text {rest }}$. To characterize the properties of evoked AP discharge, intracellular current injections (delivered in $2.5 \mathrm{pA}$ increments at $50 \mathrm{~ms}$ duration) were applied from $V_{\text {rest }}$. Rheobase was defined as the minimum current step which evoked AP discharge. AP amplitude was measured as the difference between AP threshold and the peak amplitude. The spike duration at $50 \%$ of the peak amplitude was used to calculate AP half-width.

Membrane voltages were adjusted for liquid junction potentials (approximately $-14 \mathrm{mV}$ ) calculated using JPCalc software (P. Barry, University of New South Wales, Sydney, Australia; modified for Molecular Devices). Currents were filtered at $4-6 \mathrm{kHz}$ through a $-3 \mathrm{~dB}$, 4-pole low-pass Bessel filter; digitally sampled at $20 \mathrm{kHz}$; and stored on a personal computer (ICT) using a commercially available data acquisition system (Digidata 1440A with pClamp 10.3 software; Molecular Devices).

Statistics. Data were analyzed using one-way ANOVA (with Tukey's multiple-comparisons test; Prism 5.0 software; GraphPad Software) and two-way ANOVA (with Holm-Sidak multiple-comparisons test; SigmaPlot 13.0; Systat Software) unless specified otherwise. The effects of pharmacological antagonists on baseline EPSC amplitude or t-LTP were compared between the naive and incision groups using the MannWhitney test. $n$ refers to the number of neurons sampled in a given group. Data are expressed as means \pm SEM.

$\leftarrow$

Pre $\rightarrow$ Post pairings at $\Delta t=-10 \mathrm{~ms}\left(n=6 ; p=0.0015 ; \mathrm{RM}\right.$ two-way ANOVA; ${ }^{*} p<0.05$ Bonferroni posttest). D, Chelation of postsynaptic $\mathrm{Ca}^{2+}$ with BAPTA prevented t-LTP after the administration of Pre $\rightarrow$ Post pairings at $\Delta t=-10 \mathrm{~ms}$ in mature projection neurons from both naive mice $\left(n=7\right.$ in each group; $p<0.001$; two-way ANOVA; ${ }^{* * *} p<0.001$; Holm-Sidak posttest) and neonatally incised mice ( $n=9-10 ; p<0.001$; tw0-way ANOVA; ${ }^{* * *} p<0.001$; Holm-Sidak posttest). E, Postsynaptic BAPTA application also abolished the change in pairedpulse ratio after administration of the STDP protocol ( $n=5 ; p=0.489$; RM two-way ANOVA). Results in $\boldsymbol{E}$ were obtained from projection neurons from both the naive and P3 incision groups. 
A

$$
\Delta \mathrm{t}=-20 \mathrm{~ms}(\text { Pre } \rightarrow \text { Post })
$$
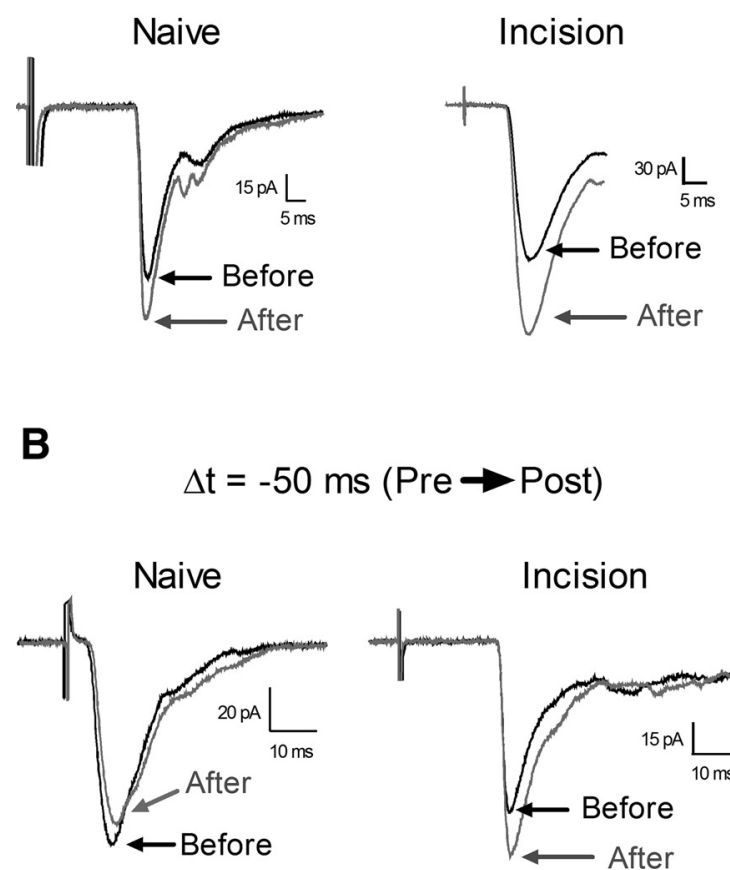
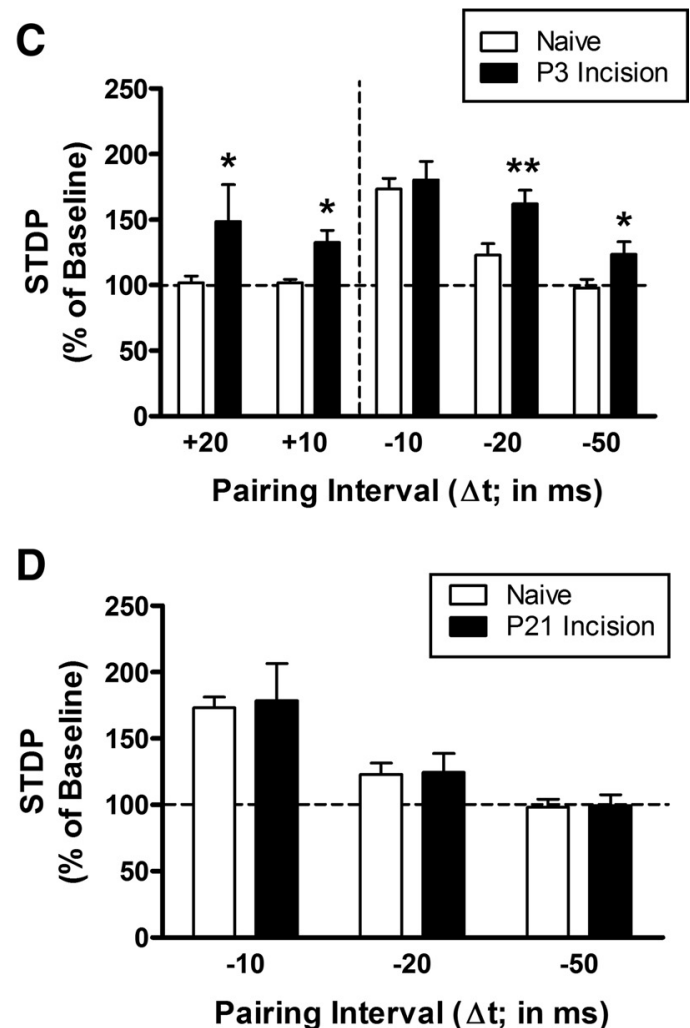

Figure 4. Tissue damage during a critical period of early life widens the temporal window for t-LTP at primary afferent synapses onto adult spinal projection neurons. $A$, Examples of monosynaptic primary afferent-evoked EPSCs recorded in mature lamina I spino-parabrachial neurons from naive mice or mice that experienced hindpaw surgical incision at $P 3$ both before (black) and after (gray) the administration of a Pre $\rightarrow$ Post pairing protocol at an interval of $-20 \mathrm{~ms}$. Note the greater magnitude oft-LTP in the incision group. Each displayed EPSC represents the average of 20 consecutive responses. $\boldsymbol{B}$, Representative traces demonstrating that Pre $\rightarrow$ Post pairings at $\Delta t=-50 \mathrm{~ms}$ failed to induce $t-$ LTP in naive projection neurons, but could potentiate afferent-evoked EPSCs in mature projection neurons when preceded by neonatal incision. Illustrated EPSCs represent the average of 20 consecutive responses. $C$, Neonatal tissue damage broadened the timing window governing t-LTP at afferent synapses onto mature projection neurons because the potentiation of EPSC amplitude was significantly greater at Pre $\rightarrow$ Post pairings of $-20 \mathrm{~ms}$ and $-50 \mathrm{~ms}$ compared with naive littermate controls $\left(n=7-9\right.$ in each group; ${ }^{*} p<0.05 ;{ }^{* *} p<0.01$; two-way ANOVA with Holm-Sidak multiple-comparisons test, right). Notably, whereas Post $\rightarrow$ Pre pairings at +10 $\mathrm{ms}$ and $+20 \mathrm{~ms}$ intervals did not alter the efficacy of primary afferent synapses onto naive projection neurons (left), $t$-LTP was observed with these reverse pairings in adult projection neurons from neonatally incised mice $\left({ }^{*} p<0.05\right.$ vs naive; two-way ANOVA with Holm-Sidak multiple-comparisons test). $\boldsymbol{D}$, Delaying the surgical injury until P21 failed to evoke the same facilitation of t-LTP at Pre $\rightarrow$ Post pairings of $-20 \mathrm{~ms}$ or $-50 \mathrm{~ms}(n=6-9$ in each group; $p=0.81$; two-way ANOVA), as was observed with P3 injury.

\section{Results}

STDP is biased toward LTP at primary afferent synapses onto spinal projection neurons

In vitro patch-clamp recordings were obtained from lamina I spinoparabrachial neurons (Fig. $1 A, B$ ) in the adult mouse spinal cord. After the measurement of baseline monosynaptic EPSCs evoked by the stimulation of primary afferents, postsynaptic APs were elicited via intracellular current injection at an interval $(\Delta t)$ either before or after the onset of the afferent-evoked EPSP. As shown in Figure $1 C$, the administration of a pairing protocol $(30$ trials at $0.2 \mathrm{~Hz})$ in which the postsynaptic activity preceded the presynaptic input (i.e., Post $\rightarrow$ Pre) failed to influence the amplitude of the afferent-evoked EPSC. However, in the same neuron, the reversal of the stimulus order (Pre $\rightarrow$ Post) led to a marked potentiation of EPSC amplitude (Fig. $1 D)$. Highly correlated Pre $\rightarrow$ Post pairings $(\Delta t=-10 \mathrm{~ms})$ consistently evoked t-LTP in lamina I projection neurons (Figs. $1 E, 2 A$ ), which averaged $173 \pm 8 \%$ of baseline ( $p<0.001$ vs control groups; one-way ANOVA with Tukey's multiple-comparisons test; $n=7$; Fig. 2E). Surprisingly, there was no evidence that the reverse Post $\rightarrow$ Pre pairings (at $\Delta t=+10 \mathrm{~ms}$ ) evoked timing-dependent long-term depression (LTD) ( $n=7$; Fig. $2 B, E)$, as would be predicted if the synaptic plasticity followed strict Hebbian mechanisms (Dan and Poo, 2004). Control experiments involving the repetitive stimulation of the primary afferents $(n=7$; Fig. $2 C)$ or projection neuron alone ( $n=5$; Fig. $2 D)$ did not alter EPSC amplitude (Fig. $2 E$ ), demonstrating that highly correlated presynaptic and postsynaptic discharge are required to evoke STDP at sensory synapses onto naive spinal projection neurons.

As reported in our prior study (Li et al., 2015), lamina I projection neurons in the adult mouse spinal cord were found to receive monosynaptic input from multiple subtypes of primary afferents, including high-threshold $\mathrm{A} \delta$ and $\mathrm{C}$-fibers as well as putative $A \beta$ and low-threshold C-fibers. Given the number of different primary afferent inputs and the need to examine multiple pairing intervals, the available sample sizes within individual categories were insufficient to compare STDP rigorously as a function of primary afferent subtype. Because we observed no obvious differences in the ability to evoke STDP across the various classes of sensory inputs, the data were pooled for analysis. Nonetheless, the degree to which the properties of STDP might vary across different populations of sensory neurons remains unknown and is an important topic for future investigation.

\section{t-LTP at primary afferent synapses onto lamina I projection} neurons involves alterations in presynaptic function

To begin elucidating the relative contribution of presynaptic and postsynaptic mechanisms to the observed t-LTP at primary afferent synapses onto ascending projection neurons, we next 
investigated whether t-LTP was accompanied by an increased probability of glutamate release $\left(P_{\mathrm{r}}\right)$ in the superficial dorsal horn. Pairs of identical stimuli were delivered to the dorsal root at various intervals (100-500 ms) to evoke monosynaptic EPSCs in the sampled projection neuron either before or after the administration of a Pre $\rightarrow$ Post pairing protocol at $\Delta t=-10 \mathrm{~ms}$ (Fig. $3 A$ ), which produces robust t-LTP (Fig. $2 E$ ). Application of this STDP protocol significantly reduced the paired-pulse ratio in lamina I projection neurons from naive mice across the range of interstimulus intervals tested $[n=7 ; p=0.0001$; repeatedmeasures (RM) two-way ANOVA; Fig. 3B], suggesting that correlated presynaptic and postsynaptic firing elevated $P_{\mathrm{r}}$ at primary afferent synapses onto this population. Similar effects of the STDP protocol were observed at primary afferent synapses onto lamina I projection neurons from adult mice subjected to hindpaw surgical incision at P3 $(n=6 ; p=0.0015$; RM two-way ANOVA; Fig. 3C).

Interestingly, chelation of intracellular $\mathrm{Ca}^{2+}$ in the projection neuron with BAPTA suppressed t-LTP in both naive $(n=7$ in each group; $p<0.001$; two-way ANOVA with Holm-Sidak posttest for multiple comparisons; Fig. $3 D$, left) and neonatally incised mice ( $n=9-10$ in each group; $p<0.001$; Fig. $3 D$, right), demonstrating that elevations in postsynaptic $\mathrm{Ca}^{2+}$ levels are critical for the induction of t-LTP at primary afferent synapses onto adult projection neurons. Perfusion of the postsynaptic cell with BAPTA also abolished the change in paired-pulse ratios after the administration of the STDP protocol $(n=5 ; p=0.489$; RM two-way ANOVA; Fig. $3 E$ ). These results suggest that t-LTP may involve the release of a retrograde messenger from lamina I projection neurons driven by a rise in postsynaptic calcium levels, which enhances the probability of glutamate release from primary afferent terminals in the dorsal horn of both neonatally injured mice and naive littermate controls.

Neonatal tissue damage widens the timing window for t-LTP in adult lamina I projection neurons

To further investigate whether tissue injury during early life has a persistent influence on activity-dependent synaptic plasticity within mature spinal nociceptive circuits, we examined the properties of STDP across a range of pairing intervals $(\Delta t=+20$ to $-50 \mathrm{~ms}$ ) at primary afferent synapses onto lamina I projection neurons from adult mice subjected to $\mathrm{P} 3$ hindpaw incision or naive littermate controls. As illustrated in Figure $4 C$, neonatal tissue damage broadened the timing window during which presynaptic and postsynaptic activity could produce t-LTP compared with the naive group ( $p<0.001$; two-way ANOVA). Although highly correlated Pre $\rightarrow$ Post pairings ( $\Delta t=-10 \mathrm{~ms}$ ) evoked a similar magnitude of t-LTP in neonatally incised and naive mice, significantly greater t-LTP was observed in the incision group at the $\Delta t=-20 \mathrm{~ms}$ interval $(n=9$ in each group; $p=0.007$; two-way ANOVA with Holm-Sidak multiplecomparisons test; Fig. $4 A, C)$. Similarly, Pre $\rightarrow$ Post pairings at an interval of $-50 \mathrm{~ms}(\Delta t=-50 \mathrm{~ms})$ evoked t-LTP in projection neurons from injured mice, but not in the naive group $(n=7-9$; $p=0.039$; Fig. $4 B, C)$.

Interestingly, neonatal incision also abolished the strict dependence of t-LTP on the sequential activation of primary afferent inputs and spinal projection neurons. Although Post $\rightarrow$ Pre pairings $(\Delta t=+10$ or $+20 \mathrm{~ms})$ failed to affect synaptic efficacy in adult lamina I projection neurons from naive mice, t-LTP was evident in response to the same reverse pairing protocols in mice that experienced surgical incision at $\mathrm{P} 3(n=7-8$ in each group; $p=0.027$ at $+10 \mathrm{~ms}$ interval; $p=0.010$ at $+20 \mathrm{~ms}$ interval;
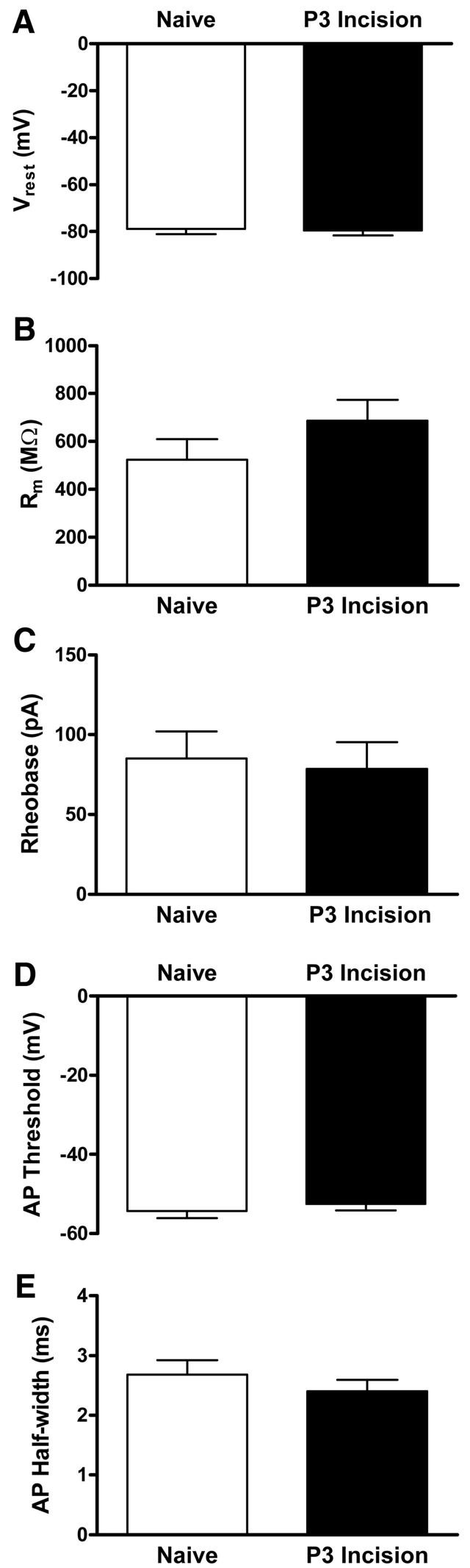

Figure 5. Early tissue damage does not modulate the intrinsic excitability of mature spinal projection neurons. $\boldsymbol{A}$, Hindpaw incision at P3 failed to significantly alter $V_{\text {rest }}$ of adult lamina I projection neurons ( $n=10-13$ in each group; $p=0.975$; Mann-Whitney test). $\boldsymbol{B}$, Membrane resistance $\left(R_{\mathrm{m}}\right)$ was also not significantly changed by early tissue damage ( $\left.p=0.227\right)$. $\boldsymbol{C}-\boldsymbol{E}$, Similarly, there were no statistically significant differences between the naive and $\mathrm{P} 3$ incision groups in terms of rheobase $(p=0.555 ; \boldsymbol{C})$, AP threshold $(p=0.756 ; \boldsymbol{D})$, or AP duration $(p=0.42 ; \boldsymbol{E})$. 
A1

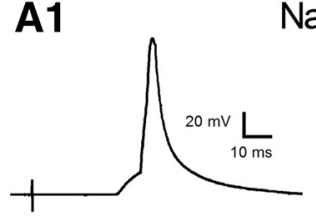

Naive
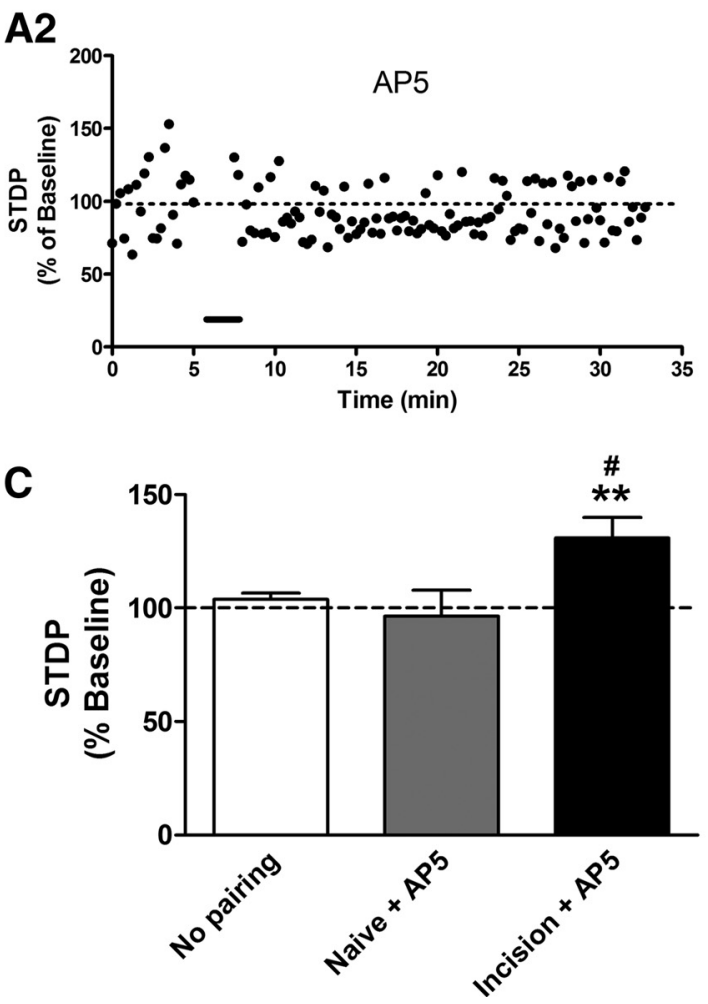

B1

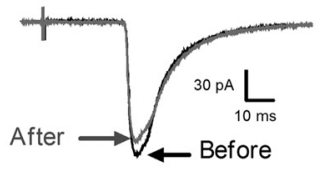

Incision

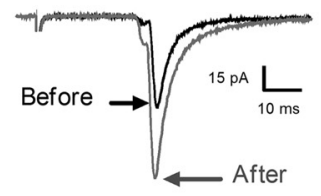

B2

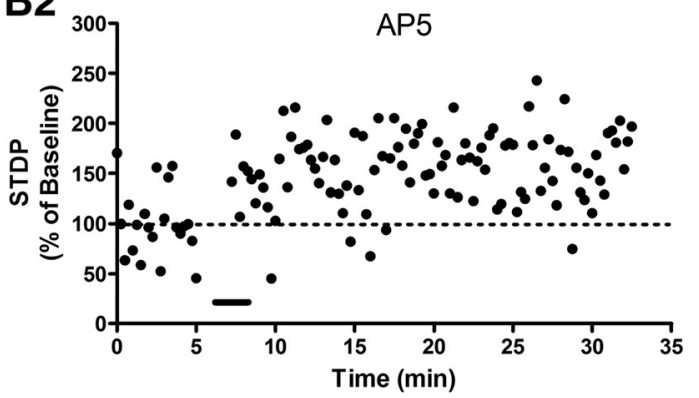

Figure 6. Neonatal surgical injury reduces the dependence of t-LTP on NMDAR activation. $\boldsymbol{A} 1$, Pre $\rightarrow$ Post pairing protocols $(\Delta t=-10 \mathrm{~ms}$, left) applied in the presence of the selective NMDAR antagonist AP5 failed to modulate EPSC amplitude at primary afferent synapses onto naive projection neurons (right). A2, STDP versus time plot from the same neuron showing the absence of t-LTP after the administration of the pairing (bar). $\mathbf{B 1}, \mathbf{B 2}$, In contrast, marked t-LTP could be observed in the presence of AP5 in lamina I projection neurons from neonatally injured mice. EPSCs shown in $\boldsymbol{A} \mathbf{1}$ and $\boldsymbol{B} 1$ correspond to an average of 20 consecutive traces. C, NMDAR block abolished t-LTP at afferent synapses onto naive projection neurons at Pre $\rightarrow$ Post pairings of $\Delta t=-10 \mathrm{~ms}$ (naive + AP5: $n=10$; no pairing control: $n=22 ; p>0.05$; one-way ANOVA with Tukey's multiple-comparisons test). Meanwhile, in adult projection neurons from mice with P3 injury ( $n=11)$, EPSC amplitude was still potentiated by the Pre $\rightarrow$ Post protocol in the presence of AP5 compared with the nonpairing controls (\#p $<0.05)$ or the naive group with AP5 $\left({ }^{* *} p<0.01\right)$.

two-way ANOVA with Holm-Sidak multiple-comparisons test; Fig. 4C). Collectively, the above results point to a more permissive environment for synaptic LTP at the output neurons within the adult spinal pain network when preceded by tissue injury during the neonatal period.

A key question is whether tissue injury at later ages can also induce prolonged metaplasticity at primary afferent synapses onto spinal projection neurons. Although a complete developmental time course has yet to be investigated, Figure $4 D$ demonstrates that hindpaw incision at P21 fails to facilitate t-LTP at the Pre $\rightarrow$ Post pairing intervals of $-20 \mathrm{~ms}$ and $-50 \mathrm{~ms}$ in adult lamina I projection neurons $(n=6-9$ in each group; $p=0.81$; two-way ANOVA). These findings are consistent with the existence of a discrete critical period during which tissue damage can evoke long-term effects on synaptic plasticity within the mature superficial dorsal horn.

Neonatal injury does not modulate the intrinsic membrane excitability of adult lamina I projection neurons

The width of the STDP window is known to be strongly regulated by the intrinsic membrane properties of the postsynaptic neuron (Dan and Poo, 2004), including the level of conductance through
A-type voltage-gated $\mathrm{K}^{+}$channels (Johnston et al., 2003) and $\mathrm{Ca}^{2+}$-activated $\mathrm{K}^{+}$channels (Watanabe et al., 2002). Therefore, the widening of the STDP window after neonatal incision (Fig. $4 C$ ) could reflect long-term changes in the intrinsic excitability of adult projection neurons. However, current-clamp recordings from mature lamina I projection neurons suggest that early injury does not alter the intrinsic membrane properties of this population because there were no significant differences between the naive $(n=13)$ and P3 incision $(n=10)$ groups in the resting membrane potential ( $p=0.975$; Mann-Whitney test; Fig. $5 A)$, membrane capacitance $(p=0.556$; data not shown $)$, membrane resistance $(p=0.227$; Fig. $5 B)$, rheobase $(p=0.555$; Fig. $5 C)$, AP threshold ( $p=0.756$; Fig. $5 D)$, or AP duration ( $p=0.42$; Fig. $5 E)$.

Early tissue damage persistently modulates the glutamatergic mechanisms underlying t-LTP in mature projection neurons t-LTP in many areas of the CNS requires the activation of NMDARs (Magee and Johnston, 1997; Markram et al., 1997). As expected, blocking NMDARs via bath application of AP5 abolished t-LTP at primary afferent synapses onto lamina I projection neurons from naive mice at the Pre $\rightarrow$ Post pairing interval of 
A

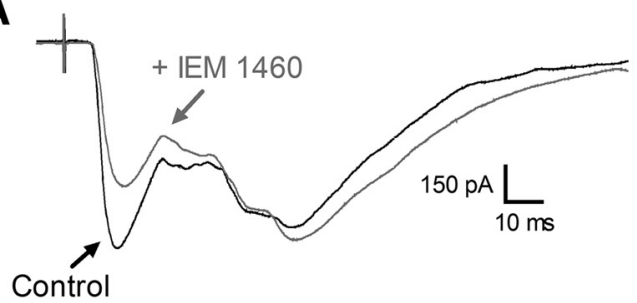

B

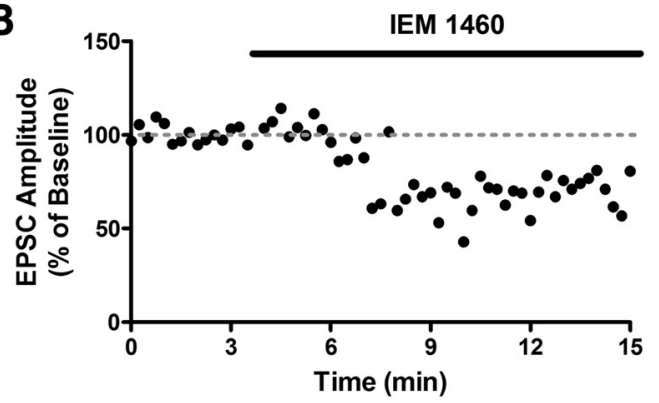

C
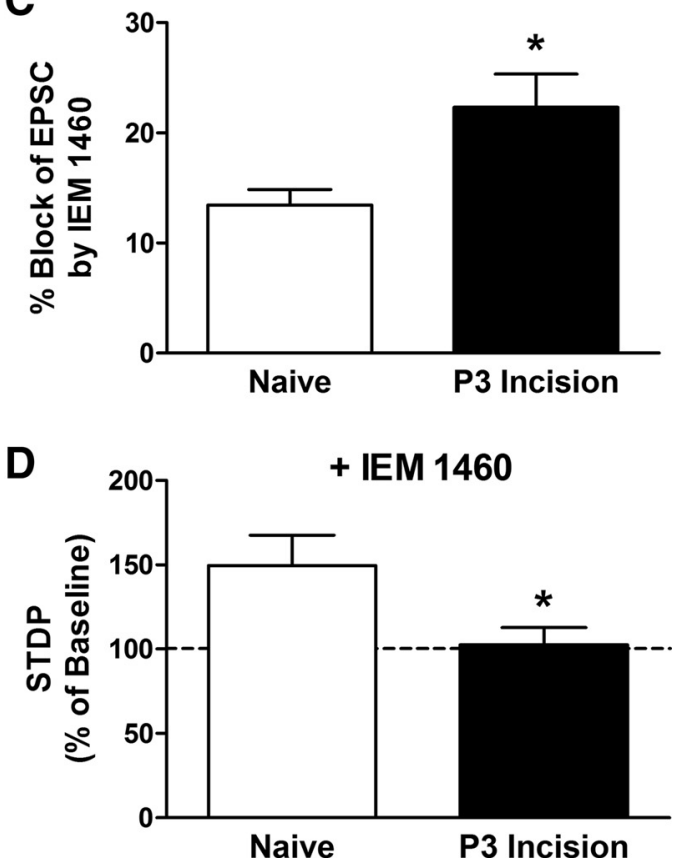

Figure 7. Early injury increases the contribution of $\mathrm{Ca}^{2+}$-permeable AMPARs to t-LTP at sensory synapses onto adult lamina I projection neurons. $A$, Representative EPSCs evoked by dorsal root stimulation before (black) and after (gray) bath application of the selective $\mathrm{Ca}^{2+}$ permeable AMPAR antagonist IEM 1460. Illustrated EPSCs represent the average of 20 consecutive responses. $\boldsymbol{B}$, Plot of normalized EPSC amplitude versus time for the same neuron depicted in $\boldsymbol{A}$. $C$, Neonatal incision significantly increased the sensitivity of the primary afferent-evoked EPSC to IEM 1460 compared with naive controls (naive: $n=7$; P3 incision: $n=7 ;{ }^{*} p=0.018$; Mann-Whitney test), suggesting an upregulation in the synaptic expression of $\mathrm{Ca}^{2+}$. permeable AMPARs within adult spino-parabrachial neurons. $\boldsymbol{D}$, Although t-LTP could be observed in naive projection neurons despite the block of $\mathrm{Ca}^{2+}$-permeable AMPARs $(n=$ 7), IEM 1460 abolished the synaptic potentiation produced by Pre $\rightarrow$ Post pairings (at $\Delta t=-10 \mathrm{~ms})$ in adult projection neurons from neonatally incised mice $\left(n=7 ;{ }^{*} p=\right.$ 0.038; Mann-Whitney test).

$-10 \mathrm{~ms}(n=10$; Fig. $6 A, C)$. Surprisingly, across the population of adult projection neurons from neonatally incised mice $(n=11)$, t-LTP was not eliminated by NMDAR blockade $(p<$ 0.05 vs the no pairing control; $p<0.01$ vs naive + AP5; one-way ANOVA with Tukey's multiple-comparisons test; Fig. 6C). In- deed, a number of projection neurons from the $\mathrm{P} 3$ incision group exhibited robust potentiation in EPSC amplitude in the presence of the NMDAR antagonist (Fig. 6B). These data suggest that early tissue damage reduces the dependence of t-LTP on NMDAR activation within mature spinal pain networks.

Given the clear dependence of t-LTP on postsynaptic $\mathrm{Ca}^{2+}$ signaling in projection neurons from both naive and neonatally incised mice (Fig. 3D), we next investigated the possibility that neonatal injury recruits a supplemental source of $\mathrm{Ca}^{2+}$ influx within spinal projection neurons to promote the generation of t-LTP at primary afferent synapses. $\mathrm{Ca}^{2+}$-permeable AMPARs are expressed in NK1R-expressing lamina I neurons (Tong and MacDermott, 2006; Vikman et al., 2008), many of which correspond to ascending projection neurons (Todd et al., 2002). First, to examine the potential long-term effects of early tissue damage on the relative expression of $\mathrm{Ca}^{2+}$-permeable AMPARs at afferent synapses onto mature projection neurons, we determined the sensitivity of EPSCs to the selective $\mathrm{Ca}^{2+}$-permeable AMPAR antagonist IEM 1460 (Fig. 7 A,B). The fraction of EPSC amplitude blocked by IEM 1460 was significantly greater in projection neurons from adult mice receiving $\mathrm{P} 3$ incision $(n=7)$ compared with naive littermate controls $(n=7 ; p=0.018$; Mann-Whitney test; Fig. 7C), suggesting an injury-evoked upregulation of $\mathrm{Ca}^{2+}$. permeable AMPARs at these synapses. In addition, whereas t-LTP was observed in naive projection neurons despite the presence of IEM 1460 during the administration of the pairing protocol $(n=7)$, the blockage of $\mathrm{Ca}^{2+}$-permeable AMPARs prevented t-LTP in mature projection neurons when preceded by neonatal surgical injury $(n=7 ; p=0.038$; Mann-Whitney test; Fig. 7D).

\section{Neonatal injury enhances f-LTP at primary afferent synapses} onto adult spinal projection neurons

To determine whether early tissue damage also facilitates other forms of activity-dependent plasticity at sensory synapses onto adult lamina I projection neurons, we next characterized f-LTP after tetanic stimulation of the attached dorsal root (Ikeda et al., 2003; Ikeda et al., 2006). In both naive (Fig. $8 A, B$ ) and P3 incision (Fig. $8 C, D$ ) groups, HFS ( 3 trains at $100 \mathrm{~Hz}, 1 \mathrm{~s}$ ) of primary afferents evoked a marked potentiation in monosynaptic EPSC amplitude that persisted for the duration of the recording. Interestingly, the magnitude of f-LTP at these synapses was significantly greater when preceded by hindpaw surgical injury at P3 $(n=7$ in each group; $p=0.026$; Mann-Whitney test; Fig. $8 E)$.

\section{Discussion}

The above results suggest for the first time that neonatal tissue injury creates a more permissive environment for the induction of t-LTP at primary afferent synapses onto the major output neurons of the adult spinal nociceptive circuit. This relaxation of the timing rules governing synaptic plasticity is predicted to increase the likelihood that an individual nociceptive input to the mature dorsal horn is strengthened after repetitive stimulation, as would occur in response to a subsequent injury during adulthood. The potentiation of afferent synapses with activity that is poorly correlated with the firing of developing projection neurons could also facilitate the conversion of subthreshold excitatory connections to suprathreshold inputs (Woolf and King, 1989; Weng and Dougherty, 2002), which may contribute to the expanded receptive fields of adult dorsal horn neurons (Torsney and Fitzgerald, 2003), as well as the greater strength of their primary afferent input ( $\mathrm{Li}$ et al., 2015) after early tissue damage. Ultimately, the increased probability of evoking LTP at sensory 


\section{Naive}

A

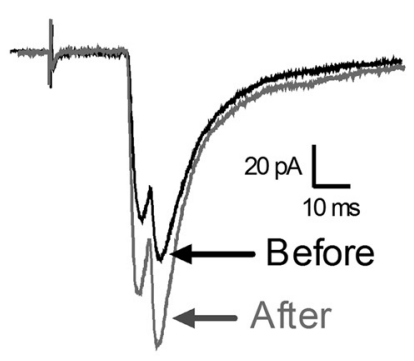

B

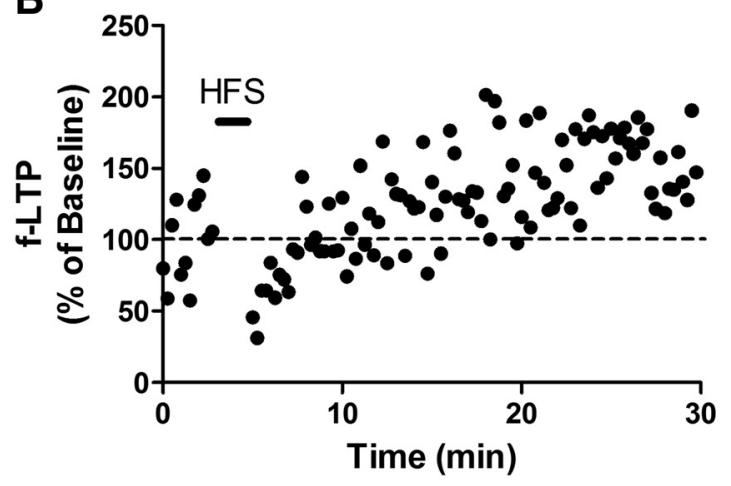

P3 Incision

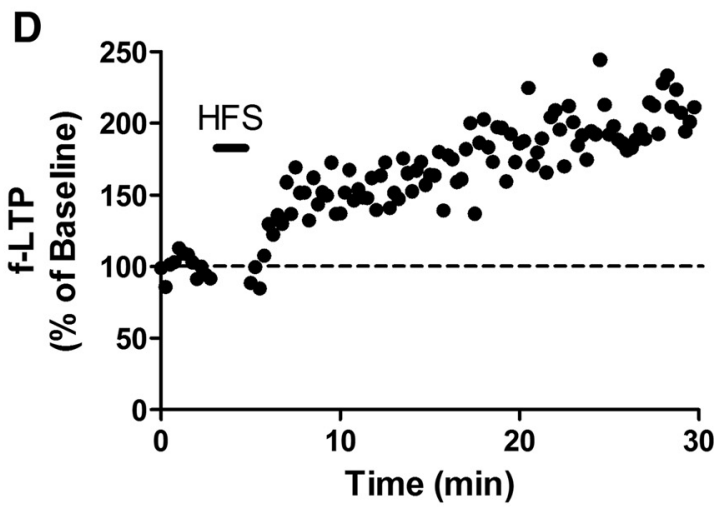

Time $(\min )$
C

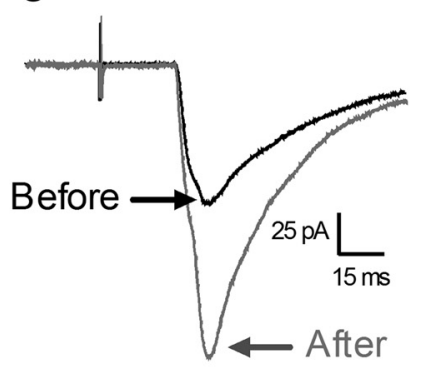

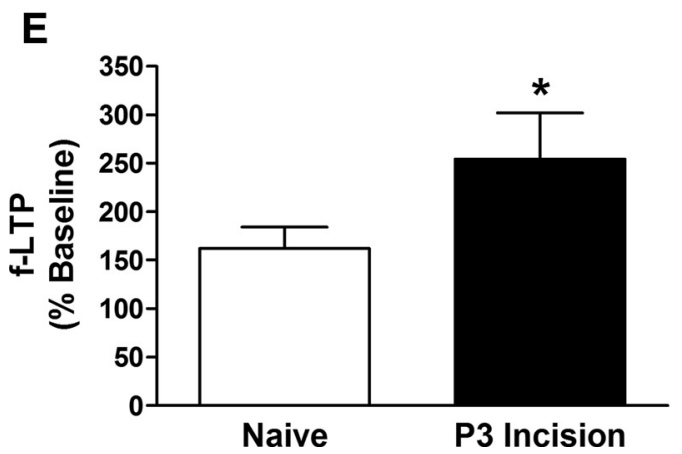

Figure 8. Early tissue damage facilitates $\mathrm{f}-\mathrm{LTP}$ at sensory inputs to mature spinal projection neurons. $A$, Representative traces of monosynaptic EPSCs evoked in a naive lamina I projection neuron (from a holding potential of $-70 \mathrm{mV}$ ) either before (black) or after (gray) the administration of HFS to the attached dorsal root. $\boldsymbol{B}$, Plot off-LTP (expressed as a percentage of baseline EPSC amplitude before HFS, where $100 \%$ indicates no change in synaptic efficacy) as a function of time for the same neuron depicted in $A$. The HFS (black bar) was delivered to the dorsal root with the projection neuron voltage clamped at $-30 \mathrm{mV}$. C, Examples of primary afferent-evoked EPSCs before and after HFS in an adult lamina I projection neuron from a mouse subjected to P3 hindpaw incision. $\boldsymbol{D}$, $\mathrm{f}$-LTP versus time plot for the neuron illustrated in C. E, Average magnitude of f-LTP was significantly greater in the P3 incision group $(n=7)$ compared with naive littermate controls $(n=7 ; p=$ 0.026; Mann-Whitney test).

synapses onto spinal projection neurons is likely to enhance the activation of an ascending pathway known to be essential for pain perception (Spiller and Martin, 1912; Stookey, 1929). In addition, the data shown in Figure 8 suggest that neonatal injury can also amplify the level of activity in the ascending nociceptive pathway by exaggerating the magnitude of synaptic LTP after the robust activation of peripheral nociceptive inputs to the mature dorsal horn. Therefore, it appears that the influence of early tissue injury on activity-dependent synaptic plasticity in the adult spinal nociceptive circuit is not restricted to the expansion of the timing window governing STDP. It will be of great interest to determine whether neonatal tissue damage also modulates synaptic strengthening in projection neurons under other conditions such as opioid withdrawal (Drdla et al., 2009).

STDP at many central synapses occurs in a Hebbian manner, with postsynaptic APs occurring soon after the onset of the presynaptic input producing LTP, while the reverse sequence evokes LTD (Markram et al., 1997; Bi and Poo, 1998; Zhang et al., 2009). Nonetheless, anti-Hebbian plasticity has also been documented at CNS synapses, where Pre $\rightarrow$ Post pairing evokes LTD and Post $\rightarrow$ Pre protocols produce LTP (Bell et al., 1997; Fino et al., 2010; Paille et al., 2013). In this context, primary afferent synapses onto 
naive projection neurons are unusual in the highly asymmetric shape of the timing window governing STDP because Pre $\rightarrow$ Post pairs evoked LTP, but the reverse sequence failed to influence synaptic efficacy (Fig. 4C). The apparent resistance to timingdependent LTD may be restricted to afferent synapses onto projection neurons because frequency-dependent LTD has been described in the superficial dorsal horn (Sandkühler et al., 1997; Liu et al., 1998). Indeed, recent work shows that the same conditioning stimulation that evokes LTP in spinothalamic neurons induces LTD in nearby GABAergic neurons, supporting the notion of cell-type-specific synaptic plasticity in the dorsal horn (Kim et al., 2015). However, unopposed LTP at primary afferent inputs onto projection neurons would eventually result in the saturation of these synapses and a loss in the ability of the dorsal horn network to encode sensory information (Bienenstock et al., 1982; Miller, 1996). Homeostatic mechanisms could contribute to the scaling down of primary afferent synapses to maintain the firing rates of projection neurons within a stable range (Turrigiano et al., 1998; Turrigiano, 1999). In addition, we cannot exclude the possibility that testing additional Post $\rightarrow$ Pre protocols would reveal timing-dependent LTD at these synapses.

Our finding that t-LTP at afferent synapses onto spinal projection neurons is abolished by internal BAPTA (Fig. 3D) is consistent with prior reports demonstrating a crucial role of intracellular $\mathrm{Ca}^{2+}$ signaling in the regulation of STDP (Bender et al., 2006; Kampa et al., 2006; Aihara et al., 2007). The backpropagation of APs into the postsynaptic dendritic tree (Stuart and Sakmann, 1994; Spruston et al., 1995) is thought to boost dendritic $\mathrm{Ca}^{2+}$ elevations by relieving the $\mathrm{Mg}^{2+}$ block of synaptic NMDARs (Mayer et al., 1984) and thereby providing an associative signal that drives LTP (Yang et al., 1999; Cho et al., 2001; Cormier et al., 2001). Dendritic $\mathrm{Ca}^{2+}$ transients in cortical pyramidal neurons are higher after Pre $\rightarrow$ Post compared with Post $\rightarrow$ Pre pairings due largely to greater $\mathrm{Ca}^{2+}$ influx via NMDARs (Koester and Sakmann, 1998). We speculate that, in adult spinal projection neurons, the elevated relative expression of $\mathrm{Ca}^{2+}$ permeable AMPARs after neonatal injury (Fig. $7 C$ ) serves to augment dendritic $\mathrm{Ca}^{2+}$ influx in response to primary afferent synaptic input, thus reducing the dependence on both NMDAR activation and the resulting strict requirement for the presynaptic input to precede postsynaptic firing. Indeed, $\mathrm{Ca}^{2+}$-permeable AMPARs drive LTP in the spinal dorsal horn after tetanic stimulation (Youn et al., 2008) and are well suited to mediate antiHebbian potentiation (as seen with Post $\rightarrow$ Pre pairs; Fig. 4C, left) due to their inward rectification (Lamsa et al., 2007). Therefore, it will ultimately be important to examine the effects of neonatal injury on intracellular $\mathrm{Ca}^{2+}$ dynamics in adult projection neurons after sensory input in vivo (Drdla et al., 2009; Laffray et al., 2011). Nonetheless, it should be noted that the timing rules for STDP can vary according to the location of the synapse within the dendritic tree, with distal synapses exhibiting LTP in response to Post $\rightarrow$ Pre stimulation (Letzkus et al., 2006). As a result, a persistent reorganization in the anatomical distribution of sensory inputs to developing projection neurons could also potentially contribute to the ability of Post $\rightarrow$ Pre pairings to evoke t-LTP when preceded by early tissue damage.

The current data suggest that the widening of the STDP window after neonatal incision (Fig. $4 C$ ) is unlikely to reflect longterm changes in the intrinsic excitability of adult projection neurons because no such changes were evident after P3 injury (Fig. 5), in contrast to the clear effects previously documented in both excitatory and inhibitory interneurons within the mature superficial dorsal horn (Li and Baccei, 2014). However, the tim- ing rules regulating STDP at excitatory synapses are also shaped by inhibitory synaptic transmission within the network because blocking $\mathrm{GABA}_{\mathrm{A}} \mathrm{Rs}$ can reverse the temporal order of plasticity at corticostriatal synapses (Fino et al., 2010; Paille et al., 2013). This is interesting because primary afferent-evoked "feedforward" inhibition of adult spinal projection neurons is significantly compromised after neonatal surgical injury (Li et al., 2015). In addition, STDP is highly sensitive to the activation of neuromodulatory systems in the CNS (Pawlak et al., 2010), with the activation of $G_{\mathrm{s}}$-coupled receptors favoring the induction of t-LTP, whereas $G_{q / 11}$-coupled receptors appear to promote LTD (Seol et al., 2007; Zhang et al., 2009). For example, the activation of D1-like receptors by dopamine alters the STDP window in hippocampal neurons such that t-LTP is evoked by both Pre $\rightarrow$ Post and Post $\rightarrow$ Pre pairings (Zhang et al., 2009). This raises the possibility that persistent injury-evoked alterations in the expression of G-protein-coupled receptors (GPCRs) in spinal projection neurons contribute to the widening of the t-LTP window. Notably, neonatal hindpaw injury alters the expression of several genes encoding GPCRs in the adult dorsal horn (Ren et al., 2005). Persistent changes in G-protein signaling could also occur independently of alterations in GPCR expression because tissue damage can evoke constitutive G-protein activity in the spinal cord (Corder et al., 2013).

In conclusion, the significant widening of the timing window governing t-LTP in adult projection neurons could represent a novel potential mechanism by which neonatal tissue damage can prime mature spinal nociceptive circuits and thereby contribute to the exacerbation of pain severity after repeat injury during later life.

\section{References}

Aihara T, Abiru Y, Yamazaki Y, Watanabe H, Fukushima Y, Tsukada M (2007) The relation between spike-timing dependent plasticity and $\mathrm{Ca} 2+$ dynamics in the hippocampal CA1 network. Neuroscience 145: 80-87. CrossRef Medline

Beggs S, Currie G, Salter MW, Fitzgerald M, Walker SM (2012) Priming of adult pain responses by neonatal pain experience: maintenance by central neuroimmune activity. Brain 135:404-417. CrossRef Medline

Bell CC, Han VZ, Sugawara Y, Grant K (1997) Synaptic plasticity in a cerebellum-like structure depends on temporal order. Nature 387: 278-281. CrossRef Medline

Bender VA, Bender KJ, Brasier DJ, Feldman DE (2006) Two coincidence detectors for spike-timing-dependent plasticity in somatosensory cortex. J Neurosci 26:4166-4177. CrossRef Medline

Bi GQ, Poo MM (1998) Synaptic modifications in cultured hippocampal neurons: dependence on spike timing, synaptic strength, and postsynaptic cell type. J Neurosci 18:10464-10472. Medline

Bienenstock EL, Cooper LN, Munro PW (1982) Theory for the development of neuron selectivity: orientation specificity and binocular interaction in visual cortex. J Neurosci 2:32-48. Medline

Brennan TJ, Vandermeulen EP, Gebhart GF (1996) Characterization of a rat model of incisional pain. Pain 64:493-501. CrossRef Medline

Carbajal R, Rousset A, Danan C, Coquery S, Nolent P, Ducrocq S, Saizou C, Lapillonne A, Granier M, Durand P, Lenclen R, Coursol A, Hubert P, de Saint Blanquat L, Boëlle PY, Annequin D, Cimerman P, Anand KJ, Bréart G (2008) Epidemiology and treatment of painful procedures in neonates in intensive care units. JAMA 300:60-70. CrossRef Medline

Cho K, Aggleton JP, Brown MW, Bashir ZI (2001) An experimental test of the role of postsynaptic calcium levels in determining synaptic strength using perirhinal cortex of rat. J Physiol 532:459-466. CrossRef Medline

Chu YC, Chan KH, Tsou MY, Lin SM, Hsieh YC, Tao YX (2007) Mechanical pain hypersensitivity after incisional surgery is enhanced in rats subjected to neonatal peripheral inflammation: effects of $\mathrm{N}$-methyl-D-aspartate receptor antagonists. Anesthesiology 106:1204-1212. CrossRef Medline

Corder G, Doolen S, Donahue RR, Winter MK, Jutras BL, He Y, Hu X, Wieskopf JS, Mogil JS, Storm DR, Wang ZJ, McCarson KE, Taylor BK (2013) Constitutive mu-opioid receptor activity leads to long-term en- 
dogenous analgesia and dependence. Science 341:1394-1399. CrossRef Medline

Cormier RJ, Greenwood AC, Connor JA (2001) Bidirectional synaptic plasticity correlated with the magnitude of dendritic calcium transients above a threshold. J Neurophysiol 85:399-406. Medline

Dan Y, Poo MM (2004) Spike-timing-dependent plasticity of neural circuits. Neuron 44:23-30. CrossRef Medline

Drdla R, Gassner M, Gingl E, Sandkühler J (2009) Induction of synaptic long-term potentiation after opioid withdrawal. Science 325:207-210. CrossRef Medline

Fino E, Paille V, Cui Y, Morera-Herreras T, Deniau JM, Venance L (2010) Distinct coincidence detectors govern the corticostriatal spike-timingdependent plasticity. J Physiol 588:3045-3062. CrossRef Medline

Gerkin RC, Lau PM, Nauen DW, Wang YT, Bi GQ (2007) Modular competition driven by NMDA receptor subtypes in spike-timing-dependent plasticity. J Neurophysiol 97:2851-2862. CrossRef Medline

Hermann C, Hohmeister J, Demirakça S, Zohsel K, Flor H (2006) Longterm alteration of pain sensitivity in school-aged children with early pain experiences. Pain 125:278-285. CrossRef Medline

Hohmann AG, Neely MH, Piña J, Nackley AG (2005) Neonatal chronic hind paw inflammation alters sensitization to intradermal capsaicin in adult rats: a behavioral and immunocytochemical study. J Pain 6: 798-808. CrossRef Medline

Hohmeister J, Kroll A, Wollgarten-Hadamek I, Zohsel K, Demirakça S, Flor H, Hermann C (2010) Cerebral processing of pain in school-aged children with neonatal nociceptive input: an exploratory fMRI study. Pain 150:257-267. CrossRef Medline

Huang S, Huganir RL, Kirkwood A (2013) Adrenergic gating of Hebbian spike-timing-dependent plasticity in cortical interneurons. J Neurosci 33: 13171-13178. CrossRef Medline

Ikeda H, Heinke B, Ruscheweyh R, Sandkühler J (2003) Synaptic plasticity in spinal lamina I projection neurons that mediate hyperalgesia. Science 299:1237-1240. CrossRef Medline

Ikeda H, Stark J, Fischer H, Wagner M, Drdla R, Jäger T, Sandkühler J (2006) Synaptic amplifier of inflammatory pain in the spinal dorsal horn. Science 312:1659-1662. CrossRef Medline

Johnston D, Christie BR, Frick A, Gray R, Hoffman DA, Schexnayder LK, Watanabe S, Yuan LL (2003) Active dendrites, potassium channels and synaptic plasticity. Philos Trans R Soc Lond B Biol Sci 358:667-674. CrossRef Medline

Kampa BM, Letzkus JJ, Stuart GJ (2006) Requirement of dendritic calcium spikes for induction of spike-timing-dependent synaptic plasticity. J Physiol 574:283-290. CrossRef Medline

Kim HY, Jun J, Wang J, Bittar A, Chung K, Chung JM (2015) Induction of long-term potentiation and long-term depression is cell-type specific in the spinal cord. Pain 156:618-625. CrossRef Medline

Koester HJ, Sakmann B (1998) Calcium dynamics in single spines during coincident pre- and postsynaptic activity depend on relative timing of back-propagating action potentials and subthreshold excitatory postsynaptic potentials. Proc Natl Acad Sci U S A 95:9596-9601. CrossRef Medline

Laffray S, Pagès S, Dufour H, De Koninck P, De Koninck Y, Cote D (2011) Adaptive movement compensation for in vivo imaging of fast cellular dynamics within a moving tissue. PLoS One 6:e19928. CrossRef Medline

Lamsa KP, Heeroma JH, Somogyi P, Rusakov DA, Kullmann DM (2007) Anti-Hebbian long-term potentiation in the hippocampal feedback inhibitory circuit. Science 315:1262-1266. CrossRef Medline

Larsen RS, Rao D, Manis PB, Philpot BD (2010) STDP in the developing sensory neocortex. Front Synaptic Neurosci 2:9. CrossRef Medline

Letzkus JJ, Kampa BM, Stuart GJ (2006) Learning rules for spike-timingdependent plasticity depend on dendritic synapse location. J Neurosci 26:10420-10429. CrossRef Medline

Li J, Baccei ML (2014) Neonatal tissue injury reduces the intrinsic excitability of adult mouse superficial dorsal horn neurons. Neuroscience 256: 392-402. CrossRef Medline

Li J, Blankenship ML, Baccei ML (2013) Deficits in glycinergic inhibition within adult spinal nociceptive circuits after neonatal tissue damage. Pain 154:1129-1139. CrossRef Medline

Li J, Kritzer E, Craig PE, Baccei ML (2015) Aberrant synaptic integration in adult lamina I projection neurons following neonatal tissue damage. J Neurosci 35:2438-2451. CrossRef Medline

Liu XG, Morton CR, Azkue JJ, Zimmermann M, Sandkühler J (1998) Long- term depression of C-fibre-evoked spinal field potentials by stimulation of primary afferent A delta-fibres in the adult rat. Eur J Neurosci 10: 3069-3075. CrossRef Medline

Magee JC, Johnston D (1997) A synaptically controlled, associative signal for Hebbian plasticity in hippocampal neurons. Science 275:209-213. CrossRef Medline

Mantyh PW, Rogers SD, Honore P, Allen BJ, Ghilardi JR, Li J, Daughters RS, Lappi DA, Wiley RG, Simone DA (1997) Inhibition of hyperalgesia by ablation of lamina I spinal neurons expressing the substance P receptor. Science 278:275-279. CrossRef Medline

Markram H, Lübke J, Frotscher M, Sakmann B (1997) Regulation of synaptic efficacy by coincidence of postsynaptic APs and EPSPs. Science 275: 213-215. CrossRef Medline

Mayer ML, Westbrook GL, Guthrie PB (1984) Voltage-dependent block by $\mathrm{Mg} 2+$ of NMDA responses in spinal cord neurones. Nature 309:261-263. CrossRef Medline

Miller KD (1996) Synaptic economics: competition and cooperation in synaptic plasticity. Neuron 17:371-374. CrossRef Medline

Nichols ML, Allen BJ, Rogers SD, Ghilardi JR, Honore P, Luger NM, Finke MP, Li J, Lappi DA, Simone DA, Mantyh PW (1999) Transmission of chronic nociception by spinal neurons expressing the substance P receptor. Science 286:1558-1561. CrossRef Medline

Paille V, Fino E, Du K, Morera-Herreras T, Perez S, Kotaleski JH, Venance L (2013) GABAergic circuits control spike-timing-dependent plasticity. J Neurosci 33:9353-9363. CrossRef Medline

Pawlak V, Wickens JR, Kirkwood A, Kerr JN (2010) Timing is not Everything: Neuromodulation Opens the STDP Gate. Front Synaptic Neurosci 2:146. CrossRef Medline

Paxinos G and Franklin KBJ (2012) The mouse brain in stereotaxic coordinates, Ed 4. London: Academic.

Ren K, Anseloni V, Zou SP, Wade EB, Novikova SI, Ennis M, Traub RJ, Gold MS, Dubner R, Lidow MS (2004) Characterization of basal and re-inflammation-associated long-term alteration in pain responsivity following short-lasting neonatal local inflammatory insult. Pain 110: 588-596. CrossRef Medline

Ren K, Novikova SI, He F, Dubner R, Lidow MS (2005) Neonatal local noxious insult affects gene expression in the spinal dorsal horn of adult rats. Mol Pain 1:27. CrossRef Medline

Ruscheweyh R, Wilder-Smith O, Drdla R, Liu XG, Sandkühler J (2011) Long-term potentiation in spinal nociceptive pathways as a novel target for pain therapy. Mol Pain 7:20. CrossRef Medline

Sandkühler J, Gruber-Schoffnegger D (2012) Hyperalgesia by synaptic long-term potentiation (LTP): an update. Curr Opin Pharmacol 12: 18-27. CrossRef Medline

Sandkühler J, Chen JG, Cheng G, Randić M (1997) Low-frequency stimulation of afferent Adelta-fibers induces long-term depression at primary afferent synapses with substantia gelatinosa neurons in the rat. J Neurosci 17:6483-6491. Medline

Seol GH, Ziburkus J, Huang S, Song L, Kim IT, Takamiya K, Huganir RL, Lee HK, Kirkwood A (2007) Neuromodulators control the polarity of spiketiming-dependent synaptic plasticity. Neuron 55:919-929. CrossRef Medline

Shouval HZ, Bear MF, Cooper LN (2002) A unified model of NMDA receptor-dependent bidirectional synaptic plasticity. Proc Natl Acad Sci U S A 99:10831-10836. CrossRef Medline

Spiller WG, Martin E (1912) The treatment of persistent pain of organic origin in the lower part of the body by division of the anterolateral column of the spinal cord. JAMA LVIII:1489-1490. CrossRef

Spruston N, Schiller Y, Stuart G, Sakmann B (1995) Activity-dependent action potential invasion and calcium influx into hippocampal CA1 dendrites. Science 268:297-300. CrossRef Medline

Stevens B, McGrath P, Gibbins S, Beyene J, Breau L, Camfield C, Finley A, Franck L, Howlett A, McKeever P, O’Brien K, Ohlsson A, Yamada J (2003) Procedural pain in newborns at risk for neurologic impairment. Pain 105:27-35. CrossRef Medline

Stookey B (1929) Further light on the transmission of pain and temperature within the spinal cord: human cordotomy to abolish pain sense without destroying temperature sense. J Nerve Ment Dis 69:552-557. CrossRef

Stuart GJ, Sakmann B (1994) Active propagation of somatic action potentials into neocortical pyramidal cell dendrites. Nature 367:69-72. CrossRef Medline 
Ting JT, Chen Q, Feng G (2011) Improved methods for acute brain slice preparation from adult and aging animals. Soc Neurosci Abstr 37:520.29.

Todd AJ, Puskar Z, Spike RC, Hughes C, Watt C, Forrest L (2002) Projection neurons in lamina I of rat spinal cord with the neurokinin 1 receptor are selectively innervated by substance p-containing afferents and respond to noxious stimulation. J Neurosci 22:4103-4113. Medline

Tong CK, MacDermott AB (2006) Both Ca2+-permeable and -impermeable AMPA receptors contribute to primary synaptic drive onto rat dorsal horn neurons. J Physiol 575:133-144. CrossRef Medline

Torsney C, Fitzgerald M (2003) Spinal dorsal horn cell receptive field size is increased in adult rats following neonatal hindpaw skin injury. J Physiol 550:255-261. CrossRef Medline

Turrigiano GG (1999) Homeostatic plasticity in neuronal networks: the more things change, the more they stay the same. Trends Neurosci 22: 221-227. CrossRef Medline

Turrigiano GG, Leslie KR, Desai NS, Rutherford LC, Nelson SB (1998) Activity-dependent scaling of quantal amplitude in neocortical neurons. Nature 391:892-896. CrossRef Medline

Vikman KS, Rycroft BK, Christie MJ (2008) Switch to Ca2+-permeable AMPA and reduced NR2B NMDA receptor-mediated neurotransmission at dorsal horn nociceptive synapses during inflammatory pain in the rat. J Physiol 586:515-527. CrossRef Medline

Walker SM, Tochiki KK, Fitzgerald M (2009) Hindpaw incision in early life increases the hyperalgesic response to repeat surgical injury: critical period and dependence on initial afferent activity. Pain 147:99-106. CrossRef Medline

Watanabe S, Hoffman DA, Migliore M, Johnston D (2002) Dendritic $\mathrm{K}+$ channels contribute to spike-timing dependent long-term potentiation in hippocampal pyramidal neurons. Proc Natl Acad Sci U S A 99:8366-8371. CrossRef Medline

Weng HR, Dougherty PM (2002) Tuning of membrane properties regulates subliminal synapses in dorsal horn neurons of intact rats. Exp Neurol 175:209-215. CrossRef Medline

Woolf CJ, King AE (1989) Subthreshold components of the cutaneous mechanoreceptive fields of dorsal horn neurons in the rat lumbar spinal cord. J Neurophysiol 62:907-916. Medline

Yang SN, Tang YG, Zucker RS (1999) Selective induction of LTP and LTD by postsynaptic [Ca2+]i elevation. J Neurophysiol 81:781-787. Medline

Youn DH, Royle G, Kolaj M, Vissel B, Randić M (2008) Enhanced LTP of primary afferent neurotransmission in AMPA receptor GluR2-deficient mice. Pain 136:158-167. CrossRef Medline

Zhang JC, Lau PM, Bi GQ (2009) Gain in sensitivity and loss in temporal contrast of STDP by dopaminergic modulation at hippocampal synapses. Proc Natl Acad Sci U S A 106:13028-13033. CrossRef Medline 